\title{
OPEM
}

www.opem.org

Oriental Pharmacy and Experimental Medicine 2009 9(2), 128-134

DOI 10.3742/OPEM.2009.9.2.128

\section{In vitro anti oxidant activity of methanol extract of Clerodendrum infortunatum Linn}

\author{
Santanu Sannigrahi ${ }^{1, *}$, Upal Kanti Mazumder ${ }^{2}$, Dilip Kumar Pal ${ }^{3}$ and Sambit Parida ${ }^{1}$ \\ ${ }^{1}$ Department of Pharmaceutical Chemistry, College of Pharmaceutical Sciences, Mohuda, Berhampur-760002, \\ Orissa, India; ${ }^{2}$ Department of Pharmaceutical Technology, Jadavpur University, Kolkata - 700 032, West Bengal, India; \\ ${ }^{3}$ Department of Pharmaceutical Chemistry, Seemanta Institute of Pharmaceutical Sciences, Jharpokharia, \\ Mayurbhanj-757 086, Orissa, India
}

Received for publication May 06, 2008; accepted February 09, 2009

\begin{abstract}
SUMMARY
The antioxidant potency of methanolic extract Clerodendrum infortunatum Linn. (MECI), which are widely used in the Indian indigenous system of medicine for different purposes, was studied. The antioxidant potential was evaluated using different established in vitro antioxidant tests viz. determination of total amount of polyphenolics compounds, DPPH (1,1-diphenyl-2-picrylhydrazyl) radical scavenging, nitric oxide scavenging, superoxide anion radical scavenging, hydroxyl radical scavenging and reductive power assay. It was found that MECI contain a high amount of polyphenolics and possesses significant free radical scavenging activity in all the assay. The higher activity was may be due to presence of richest amount of polyphenolics and flavonoids in it.
\end{abstract}

Key words: Antioxidant activity; Clerodendrum infortunatum; Free radical scavenging; Polyphenolics

\section{INTRODUCTION}

Free radicals, the partially reduced metabolites of oxygen, are highly toxic and reactive. Free radicals linked with the causation of majority of diseases like aging, atherosclerosis, cancer, diabetes, liver cirrhosis, cardiovascular disorders etc (Gutteridgde, 1995; Aruoma, 1998). The most common reactive oxygen species are superoxide anion, hydrogen peroxide, peroxyl radical and reactive hydroxyl radical. The nitrogen derived free radicals are nitric oxide and peroxynitrite anion. Oxidation process is one of the most important route for producing free

*Correspondence: Santanu Sannigrahi, St. Peter's Institute of Pharmaceutical Sciences, Hanamkonda, Warangal506001, Andhra Pradesh, India. Tel: +919177257087; Fax: +9108702567304; E-mail: santanuin@rediffmail.com radicals in food, drugs and even living systems. Antioxidant are the substances that when present in low concentration significantly delays or reduces the oxidation of the substrate (Halliwell, 2000). Antioxidants protect the body damaging oxidation reactions by reacting with free radicals and other reactive oxygen species within the body and hindering the process of oxidation. So diseases linked with free radicals can be prevented by antioxidant therapy which gained an immense importance. Current research is now directed towards finding naturally occurring antioxidants mainly of plant origin. Currently available synthetic antioxidants like butylated hydroxy anisole (BHA), butylated hydroxy toluene (BHT), tertiary butylated hydroquinone and gallic acid esters, have been suspected to cause or prompt negative health effects. Hence, strong restrictions 
have been placed on their application and there is a trend to substitute them with naturally occurring antioxidants. Moreover, these synthetic antioxidants also show low solubility and moderate antioxidant activity (Branen, 1975). BHA and BHT are suspected of being responsible for liver damage and carcinogenesis (Wichi, 1986; Grice, 1988). Traditionally used natural antioxidants from tea, wine, fruits, vegetables and spices and some natural antioxidants (e.g. rosemary and sage) are already exploited commercially either as antioxidant additives or a nutritional supplements (Schuler, 1990). Also many other plant species have been investigated in the search for novel antioxidants (Koleva et al., 2002; Auddy et al., 2003; Parejo et al., 2003) but still there is a huge need to find more information concerning the antioxidant potential of plant species. It has been mentioned the antioxidant activity of plants might be due to their phenolic compounds (Cook and Samman, 1996). Flavonoids are a group of polyphenolic compounds with known properties which include free radical scavenging, inhibition of hydrolytic and oxidative enzymes and anti-inflammatory action (Frautchy et al., 2001; Wang et al., 2006; Clavin et al., 2007). The use of traditional medicine is widespread and plants still present a large source of natural antioxidants that might serve as leads for the development of novel drugs.

Clerodendrum infortunatum Linn. (Family: Verbanaceae), a terrestrial shrub having square, blackish stem and simple, opposite, decussate, petiolate, exstipulate, coriacious, hairy leaves with a disagreeable odour (Kirtikar and Basu, 2001). Different species of Clerodendrum genus have been traditionally used over centuries and promising therapeutic and antioxidant potential have already been proved (Rajlakshmi et al., 2003; Chae et al., 2004; Chae et al., 2005; Gopal and Sengottuvelu, 2008). Clerodendrum infortunatum is very common throughout the plains of India, found widely in West Bengal. Various parts of the plant are used by tribes in colic, scorpion sting and snake bite, tumors and certain skin diseases (Nadkarni and Nadkarni, 2002). The leaves are slightly bitter, cure inflammation, skin diseases and good in small pox (Chopra et al., 1992). The plant was found to contain triterpenes, steroids and flavonoids (Joshi et al., 1978; Sinha et al., 1981; Akihisa et al., 1989). The antimicrobial (Rajakaruna et al., 2002) and anti-malarial (Goswami et al., 1998) properties of the plant has further created an upsurge in investigations on the plant.

Therefore the objective of present study were to determine the amount of total polyphenolic compounds and to evaluate the in vitro antioxidant activity of methanolic extract of $C$. infortunatum (MECI) through different free radical scavenging assay.

\section{MATERIALS AND METHODS}

\section{Plant material and extraction}

Fresh leaves of the plant were collected in the month of December, 2005 and identified by Dr. H. J. Chowdhury, Joint Director, Botanical Survey of India, Howrah, West Bengal, India. The voucher specimen (DKP 02/2005) has been deposited in the laboratory for further reference. After collection the leaves were washed properly and fungal leaves were picked out. Air-dried and powdered leaves $(1.5 \mathrm{~kg})$ were extracted successively with petroleum ether $\left(60-80^{\circ} \mathrm{C}\right)$ and methanol using Soxhlet apparatus. The solvents were distilled off and evaporated to dryness in vacuo to leave the crude methanol extract $(95 \mathrm{~g})$.

\section{Phytochemical screening}

A preliminary phytochemical screening of methanol extract was carried out as described by Khandelwal (2000).

\section{Determination total polyphenolic compounds}

The concentration of phenolic content of the methanol extract was determined with Folin-Ciocalteu reagent (FCR) according to the method of Slinkard and Singleton (1977). One millilitre of the solution (contains $1 \mathrm{mg}$ ) of the extract in methanol was 
added to $46 \mathrm{ml}$ of distilled water and $1 \mathrm{ml}$ of FCR, and mixed thoroughly. After $3 \mathrm{~min}, 3 \mathrm{ml}$ of sodium carbonate $(2 \%)$ were added to the mixture and shaken intermittently for $2 \mathrm{~h}$ at room temperature. The absorbance was read at $760 \mathrm{~nm}$. The concentration of phenolic compounds was calculated according to the following equation that was obtained from standard pyrocatechol graph:

Absorbance $=0.001$ pyrocatechol $(\mu \mathrm{g})+0.0033$

\section{DPPH radical scavenging activity}

The DPPH assay measured hydrogen atom (or one electron) donating activity and hence provided an evaluation of antioxidant activity due to free radical scavenging. DPPH, a purple-coloured stable free radical, was reduced into the yellow-coloured diphenylpicryl hydrazine which is measured spectrophotometrically at $517 \mathrm{~nm}$ (Blois, 1968). Briefly, $0.1 \mathrm{mM}$ solution of DPPH radical solution in methanol was prepared and $1 \mathrm{ml}$ of this solution was mixed with $3 \mathrm{ml}$ of sample solutions in water at different concentrations. Finally, after $30 \mathrm{~min}$, the absorbance was measured at $517 \mathrm{~nm}$. Decreasing of the DPPH solution absorbance indicates an increase of the DPPH radical-scavenging activity. This activity is given as \% DPPH radical-scavenging that was calculated according to the following equation:

$\%$ Inhibition $\left.=\left(\mathrm{A}_{0}-\mathrm{A}_{1}\right) / \mathrm{A}_{0} \times 100\right)$

Where $\mathrm{A}_{0}$ was the absorbance of the control (without extract) and $A_{1}$ was the absorbance in the presence of the extract.

\section{Nitric oxide scavenging activity}

Nitric oxide was generated from sodium nitroprusside, which at physiological $\mathrm{pH}$ liberates nitric acid. This nitric acid gets converted to nitrous acid and further forms nitrite ions $\left(\mathrm{NO}_{2}^{-}\right)$which diazotize with sulphanilic acid and couple with naphthylethylenediamine (Griess reagent), producing pink color which can be measured at $546 \mathrm{~nm}$ (Marcocci et al., 1994). Sodium nitroprusside (10 mM, $2 \mathrm{ml})$ in phosphate buffer saline was incubated with the extract in different concentrations at room temperature for $30 \mathrm{~min}$. After $30 \mathrm{~min}, 0.5 \mathrm{ml}$ of the incubated solution was added with $1 \mathrm{ml}$ of Griess reagent and the absorbance was measured at $546 \mathrm{~nm}$. The nitric oxide radicals scavenging activity was calculated according to the following equation:

$\%$ Inhibition $\left.=\left(\mathrm{A}_{0}-\mathrm{A}_{1}\right) / \mathrm{A}_{0} \times 100\right)$

Where $\mathrm{A}_{0}$ was the absorbance of the control (without extract) and $A_{1}$ was the absorbance in the presence of the extract.

\section{Superoxide anion scavenging assay}

The scavenging activity of the extract towards superoxide anion radicals was measured by the method of Nishimiki (1972) with slight modification. Phenazine methosulfate-nicotinamide adenine dinucleotide (PMS-NADH) system was used for the generation of superoxide anion. It was assayed by the reduction of nitroblue tetrazolium (NBT). About $1 \mathrm{ml}$ of nitro blue tetrazolium $(156 \mu \mathrm{M}), 1 \mathrm{ml}$ NADH $(468 \mu \mathrm{M})$ in $100 \mathrm{mM}$ phosphate buffer of $\mathrm{pH} 7.8$ and $0.1 \mathrm{ml}$ of extract solution of different concentrations were mixed. The reaction started by adding $100 \mu \mathrm{l}$ PMS $(60 \mu \mathrm{M})$. The reaction mixture was incubated at $25^{\circ} \mathrm{C}$ for $5 \mathrm{~min}$ and absorbance of the mixture was measured against blank samples. The percentage inhibition was determined by comparing the results of control and test samples.

\section{Hydroxy radical scavenging activity}

The formation of hydroxyl radicals $(\mathrm{OH} \cdot)$ from Fenton reagents was quantified using 2-deoxyribose oxidative degradation as described previously (Elizabeth and Rao, 1990). The principle of the assay is the quantification of the 2-deoxyribose degradation product, malonaldehyde, by its condensation with thiobarbituric acid (TBA). The reaction mixture contained deoxyribose $(2.8 \mathrm{mM})$; $\mathrm{FeCl}_{3}(100 \mathrm{mM}) ; \mathrm{KH}_{2} \mathrm{PO}_{4}-\mathrm{KOH}$ buffer $(20 \mathrm{mM}, \mathrm{pH}$ 
7.4); EDTA (100 mM); $\mathrm{H}_{2} \mathrm{O}_{2}(1.0 \mathrm{mM})$; ascorbic acid $(100 \mathrm{mM})$, and various concentrations of the extract in a final volume of $1 \mathrm{ml}$. Ferric chloride and EDTA (when added) were premixed just before addition to the reaction mixture. The reaction mixture was incubated at $37^{\circ} \mathrm{C}$ for $60 \mathrm{~min}$. After incubation at $37^{\circ} \mathrm{C}$ for $1 \mathrm{~h}, 1.0 \mathrm{ml}$ of $2.8 \%$ trichloroacetic acid and $1.0 \mathrm{ml}$ of $0.6 \%$ aqueous solution of TBA were added to $0.5 \mathrm{ml}$ of sample; test tubes were heated at $95^{\circ} \mathrm{C}$ for $15 \mathrm{~min}$ to develop the color. After a cooling period, thiobarbituric acid reactive substances (TBARS) formation was measured spectrophotometrically at $532 \mathrm{~nm}$ against an appropriate blank. The hydroxyl radical-scavenging activity was determined by comparing absorbance of the control with that of test compounds.

\section{Reducing power assay}

$\mathrm{The} \mathrm{Fe}^{3+}$ reducing power of MECI was determined by the method of Oyaizu (1986). The extract (2.5 $\mathrm{ml})$ at various concentrations was mixed with 2.5 $\mathrm{ml}$ of phosphate buffer (0.2 M, pH 6.6) and $2.5 \mathrm{ml}$ of potassium ferricyanide $\left[\mathrm{K}_{3} \mathrm{Fe}(\mathrm{CN})_{6}\right](1 \%$, w/v), followed by incubating at $50^{\circ} \mathrm{C}$ for $20 \mathrm{~min}$. The reaction was stopped by adding $2.5 \mathrm{ml}$ of trichloroacetic acid (TCA) solution $(10 \%)$ and then centrifuged at $800 \mathrm{rpm}$ for $10 \mathrm{~min} .2 .5 \mathrm{ml}$ of the supernatant was mixed with $2.5 \mathrm{ml}$ of distilled water and $0.5 \mathrm{ml}$ of ferric chloride solution $(0.1 \%$, $\mathrm{w} / \mathrm{v}$ ) and the absorbance was measured at $700 \mathrm{~nm}$.
Butylated hydroxyl toluene was used as reference standard. Higher absorbance of the reaction mixture indicated greater reducing power.

\section{Statistical analysis}

All data on all antioxidant activity tests are the average of triplicate analyses. The data were recorded as mean \pm S.D. The statistical significance of differences between groups was determined by analysis of variance (ANOVA), followed by Dunnett's test for multiple comparisons among groups. Differences of $P<0.05$ were considered statistically significant.

\section{RESULTS}

Preliminary phytochemical analysis of the methanol extract showed the presence of alkaloids, saponins, flavonoids, triterpenes. The total phenolic compounds amount in MECI was estimated as $54.5 \pm 8.23 \mu \mathrm{g}$ $\mathrm{mg}^{-1}$ pyrocatechol equivalent. All the results of the free radical scavenging potentials of MECI are depicted in Table 1 . The $\mathrm{IC}_{50}$ value of MECI and different standard antioxidants are given in Table 1. The $\mathrm{IC}_{50}$ value of methanol extract was found comparatively lower in hydroxyl radical scavenging assay $(65.8 \mu \mathrm{g} / \mathrm{ml})$. Methanol extract of $C$. infortunatum also showed concentration-dependant reductive effect (Figure 1).

Table 1. Radical scavenging activities of methanol extract of Clerodendrum infortunatum Linn. at different concentrations*

\begin{tabular}{ccccc}
\hline \multirow{2}{*}{$\begin{array}{c}\text { MECI concentration } \\
(\mu \mathrm{g} / \mathrm{ml})\end{array}$} & $\begin{array}{c}\text { DPPH radical } \\
\text { scavenging }\end{array}$ & $\begin{array}{c}\text { Nitric oxide } \\
\text { scavenging }\end{array}$ & $\begin{array}{c}\text { Superoxide } \\
\text { scavenging }\end{array}$ & $\begin{array}{c}\text { Hydroxy radical } \\
\text { scavenging }\end{array}$ \\
\cline { 2 - 5 } 10 & $22.18 \pm 3.2$ & $18.56 \pm 2.1$ & $15.35 \pm 0.99$ & $31.23 \pm 1.2$ \\
25 & $30.33 \pm 3.8$ & $28.42 \pm 3.3$ & $22.35 \pm 2.21$ & $36.65 \pm 4.5$ \\
50 & $34.25 \pm 2.9$ & $39.25 \pm 4.2$ & $32.32 \pm 1.98$ & $45.63 \pm 6.5$ \\
75 & $42.06 \pm 3.5$ & $49.36 \pm 5.3$ & $45.96 \pm 4.21$ & $52.36 \pm 4.6$ \\
100 & $58.85 \pm 4.5$ & $59.14 \pm 5.9$ & $52.36 \pm 4.44$ & $63.65 \pm 6.9$ \\
$\mathrm{IC}_{50}(\mu \mathrm{g} / \mathrm{ml})$ & 86.7 & 76.1 & 90.1 & 65.8 \\
\hline
\end{tabular}

*Values are expressed in mean \pm S.D., $n=3$. 


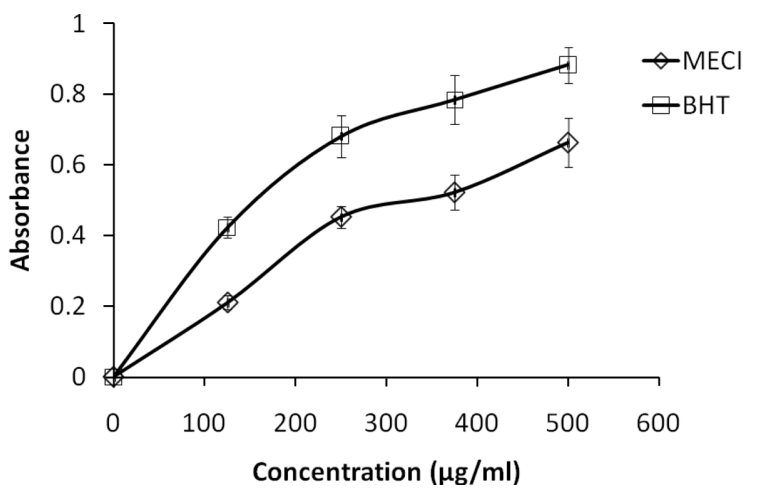

Fig. 1. Reducing power of methanol extract of Clerodendrum infortunatum Linn. and BHT by spectrophotometric detection of the $\mathrm{Fe}^{3+}-\mathrm{Fe}^{2+}$ transformations.

\section{DISCUSSION}

There are deferent models available for evaluation of antioxidant activities. The chemical complexity of different fractions and mixture of compounds present could lead to scattered results, depending on the test employed. Therefore, an approach with multiple assays for evaluating the antioxidant potential of extracts would be more informative and even necessary. The results expressed in this study are the first information on the antioxidant activities of C. infortunatum Linn. and it clearly demonstrate that the MECI can effectively scavenge various reactive oxygen species/free radicals under in vitro conditions. The high concentration of polyphenolics in the methanol extract may be responsible for its free radical scavenging activity. The FCR reducing capacity of the methanol extract may be due to presence of hydroxyl groups in the polyphenolics and flavonoids. The key role of phenolic compounds as scavengers of free radicals is emphasized in some report (Moller et al., 1999). They were reported to eliminate radicals due to their hydroxyl groups, and they contribute directly to antioxidant effect of system and it also has an important role in stabilizing lipid oxidation. The scavenging effect on DPPH radicals and superoxide radicals represent direct radical scavenging activity. Nitric oxide (NO) is a potent pleiotropic mediator of physiological processes such as smooth muscle relaxation, neuronal signaling, inhibition of platelet aggregation and regulation of cell mediated toxicity. It is a diffusible free radical which plays many roles as an effector molecule in diverse biological systems including neuronal messenger, vasodilation and antimicrobial and antitumor activities. Studies in animal models have suggested a role for $\mathrm{NO}$ in the pathogenesis of inflammation and pain and NOS inhibitors have been shown to have beneficial effects on some aspects of the inflammation and tissue changes seen in models of inflammatory bowel disease (Miller et al., 1992). The hydroxy radical is a highly potent oxidant that reacts with almost all biomolecules found in living cells. In this assay, a mixture of $\mathrm{FeCl}_{3}$-EDTA and $\mathrm{H}_{2} \mathrm{O}_{2}$ is incubated with deoxyribose in phosphate buffer ( $\mathrm{pH}$ 7.4). Deoxyribose is degraded by $\mathrm{OH}$-generated by Fenton systems and results in a series of reactions during which malondialdehyde (MDA) is formed and may be detected by its ability to react with TBA to form a pink chromogen (Halliwell et al., 1987). The reducing power assay serve as a significant indicator of its potential antioxidant activity. Although, different mechanism was proposed for their antioxidants activity such as prevention of chain initiation, binding of transition-metal ion catalysts, decomposition of peroxides, prevention of continued hydrogen abstraction, reductive capacity and radical scavenging (Gordon, 1990). The reducing properties are generally associated with the presence of different reductones (Pin-Der Duh, 1998). The antioxidant action of reductones is based on the breaking of the free radical chain by donating a hydrogen atom. Reductones also react with certain precursors of peroxide, thus preventing peroxide formation. The reductive power of different fractions may be the reason for their antioxidant activity.

MECI exhibits significant in vitro antioxidant activity through the scavenging of free radicals 
such as DPPH, nitric oxide, superoxide and hydroxyl radicals. The broad range of activity of MECI suggests that multiple mechanisms are responsible for the antioxidant activity. It is well documented that free radicals are responsible for several diseases. The present results confirm the free radical scavenging activity of the plant which can be accounted for the traditional uses of the plant in treating several diseases; however, further studies are needed with individual isolated compounds to elucidate the different antioxidant mechanism and possible synergism between the compounds.

\section{REFERENCES}

Akihisa T, Matsubara Y, Ghosp P, Thakur S, Tamura T, Matsumoto T. (1989) Sterols of some Clerodendrum species (Verbanaceae): Occurrence of the $24-\alpha-$ and $24-\beta$ - epimer of 24 ethylsterols lacking a $\delta$-25-bond. Steroids 55, 625-638.

Aruoma OI. (1998) Free radicals, oxidative stress, and antioxidants in human health and diseases. J. Am. Oil Chem. Soc. 75, 199-212.

Auddy B, Ferreira M, Blasina F, Lafon L, Arredondo F, Dajas F, Tripathi PC, Seal T, Mukherjee B. (2003) Screening of antioxidant activity of three Indian medicinal plants, traditionally used for the management of neurodegenerative diseases. J. Ethnopharmacol. 84, 131-138.

Blois MS. (1968) Antioxidant determination by the use of a stable free radical. Nature 29, 1199-1200.

Branen AL. (1975) Toxicology and biochemistry of butylated hydroxyanisol and butylated hydroxytoluene. J. Am. Oil Chem. Soc. 5, 59-63.

Chae S, Kim JS, Kang KA, Bu HD, Lee Y, Hyun JW, Kang SS. (2004) Antioxidant activity of Jionoside D from Clerodendron trichotomum. Biol. Pharm. Bull. 27, 1504-1508.

Chae S, Kim JS, Kang KA, Bu HD, Lee Y, Seo YR, Hyun JW, Kang SS. (2005) Antioxidant activity of isoacteoside from Clerodendron trichotomum. J. Toxicol. Environ. Health A. 68, 389-400.

Chopra RN, Nayer SL, Chopra IC. (1992) Glossay of Indian medicinal plant. pp. 71, Publication and
Information Directorate, CSIR, New Delhi.

Clavin M, Gorzalczany S, Macho A, Munoz E, Ferraro G, Acevedo C, Martino V. (2007) Anti-inflammatory activity of flavonoids from Eupatorium arnottianum. J. Ethnopharmacol. 12, 585-589.

Cook NC, Samman S. (1996) Flavonoids- chemistry, metabolism, cardio-protective effects, and dietary sources. Nutritional effects and dietary sources. Nutritional Biochem. 7, 66- 76.

Elizabeth K, Rao MNA. (1990) Oxygen radical scavenging activity of curcumin. Int. J. Pharma. 58, 237-240.

Frautchy SA, Hu W, Kim P, Miller SA, Chu T, HarrisWhite ME, Cole GM. (2001) Phenolic anti-inflammatory antioxidant reversal of Abeta-induced cognitive deficits and neuropathology. Neurobiol. Aging 22, 993-1005.

Gopal N, Sengottuvelu S. (2008) Hepatoprotective activity of Clerodendrum inerme against $\mathrm{CCl}_{4}$ induced hepatic injury in rats. Fitoterapia 79, 24-26.

Gordon MH. (1990) The mechanism of the antioxidant action in vitro. In Food Antioxidants, edited by Hudson BJF, pp. 1-18, Elsevier, London.

Goswami A, Dixit VK, Srivastava BK. (1998) Antimalarial activity of aqueous extract of Clerodendrum infortunatum. Bionature 48, 45-48.

Grice HP. (1988) Enhanced tumour development by butylated hydroxyanisole (BHA) from the prospective of effect on fore-stomach and oesophageal squamous epithelium. Food Chem. Toxicol. 26, 717-723.

Gutteridgde JMC. (1995) Free radicals in disease processes: A complication of cause and consequence. Free Rad. Res. Comm. 19, 141-158.

Halliwell B, Gutteridge JMC, Aruoma OI. (1987) The deoxyribose method: a simple "test-tube" assay for determination of rate constants for reactions of hydroxyl radicals. Anal. Biochem. 165, 215-219.

Halliwell B. (2000) The antioxidant paradox. Lancet 355, 1179-1180.

Joshi KC, Prakash L, Shah RK. (1978) Chemical constituents of Clerodendrum infortunatum and Ficus racemosa. J. Indian Chem. Soc. 54, 1104.

Khandelwal KR. (2000) Practical Pharmacognosy Techniques and Experiments, $9^{\text {th }}$ edition, Nirali Prkashan, Pune, India.

Kirtikar KR, Basu BD. (2001) Indian Medicinal Plants Vol. VIII, p-2686 editors Mhaskar KS, Blatter E and 
Caius JF, Sri Satguru Publications, Delhi.

Koleva II, Van Beek TA, Linssen JPH, de Groot A, Evstatieva LN. (2002) Screening of plant extracts for antioxidant activity: a comparative study on three testing methods. Phytochem. Anal. 13, 8-17.

Mantle D, Eddeb F, Pickering AT. (2000) Comparison of relative antioxidant activities of British medicinal plant species in vitro. J. Ethnopharmacol. 72, 47-51.

Marcocci L, Maguire JJ, Droy-Lafaix MT, Packer L. (1994) The nitric oxide scavenging property of Ginkgo biloba extracts EGb 761. Biochem. Biophys. Res. Commun. 201, 748-755.

Miller MJ, Sadowska-Krowicka H, Chotinaruemol S, Kakkis JL, Clark DA. (1993) Amelioration of chronic ileitis by nitric oxide synthase inhibition. J. Pharmacol. Exp. Ther. 264, 11-16.

Moller JKS, Madsen HL, Altonen T, Skibsted LH. (1999) Dittany (Origanum dictamnus) as asource of waterextractable antioxidants. Food Chem. 64, 215-219.

Nadkarni KM, Nadkarni AK. (2002) Indian Materia Medica, p. 353, Popular Publications, Mumbai.

Nishimiki M, Rao NA, Yagi K. (1972) The occurrence of superoxide anion in the reaction of reduced phenazine methosulphate and molecular oxygen. Biochem. Biophys. Res. Comm. 46, 849-853.

Oyaizu M. (1986) Studies on product of browning reaction prepared from glucose amine. Jpn. J. Nut. 44, 307-315.

Parejo I, Viladomat F, Bastida J, Rosas-Romero A, Saavedra G, Murcia MA, Jimenez AM, Codina C. (2003) Investigation of bovilian plant extracts for their radical scavenging activity and antioxidant activity. Life Sci. 73, 1667-1681.

Pin-Der Duh. (1998) Antioxidant activity of Budrock (Arctium lappa Linn): Its scavenging effect on free radical and active oxygen. J. American Oil Chem. Soc. 75, 455-461.

Rajakaruna N, Harris CS, Towers GHN. (2002) Antimicrobial Activity of Plants Collected from Serpentine Outcrops in Sri Lanka. Pharm. Biol. 40, 235-244.

Rajlakshmi D, Banerjee SK, Sood S, Maulik SK. (2003) In-vitro and in-vivo antioxidant activity of different extracts of the leaves of Clerodendron colebrookianum Walp in the rat. J. Pharm. Pharmacol. 55, 1681-1686.

Schuler P. (1990) Natural antioxidants exploited commercially. In: Food Antioxidants edited by Hudson BJF, pp. 99-170, Elsevier, London.

Sinha NK, Seth KK, Pandey VB, Dasgupta B, Shah A. (1981) Flavonoids from the flower of Clerodendrum infortunatum. Planta Med. 42, 296-298.

Slinkard K, Singleton VL. (1977) Total phenol analyses: automation and comparison with manual methods. Am. J. Enol. Vitic. 28, 49-55.

Wang L, Tu YC, Lian TW, Hung JT, Yen JH, Wu MJ. (2006) Distinctive antioxidant and anti inflammatory effects of flavonols. J. Agric. Food Chem. 54, 97989804.

Wichi HC. (1986) Safety evaluation of butylated hydroxytoluene (BHT) in the liver, lung and gastrointestinal tract. Food Chem. Toxicol. 24, 11271130. 